\title{
Significance of Trace Element Quantities in Osteomyelitis and Ewing's Sarcoma
}

\author{
Vladimir Zaichick ${ }^{1 *}$ and Sofia Zaichick ${ }^{2}$ \\ ${ }^{1}$ Radionuclide Diagnostics Department, Medical Radiological Research Centre, Russia \\ ${ }^{2}$ Feinberg School of Medicine, Northwestern University, USA
}

Submission: February 07, 2018; Published: February 23, 2018

"Correspondence Address: Vladimir Zaichick, Medical Radiological Research Centre, Korolyev St.4, Obninsk 249036, Kaluga Region, Russia, Tel: (48439) 60289; Fax: (495) 956 1440; Email: vezai@obninsk.com

\begin{abstract}
To clarify the role of trace elements (TE) in the etiology and the pathogenesis of osteomyelitis (OM) and Ewing's sarcoma (ES) of bone, a nondestructive neutron activation analysis were performed. The $\mathrm{Ag}, \mathrm{Co}, \mathrm{Cr}, \mathrm{Fe}, \mathrm{Hg}, \mathrm{Rb}, \mathrm{Sb}, \mathrm{Se}$, and $\mathrm{Zn}$ contents were measured in three groups of samples: normal bone samples from 27 persons with intact bone, and also in samples, obtained from open biopsies or after operation of 10 patients with OM and 6 patients with ES. The difference in the results between TE contents in the three groups was evaluated by the parametric Student's t-test and non-parametric Wilcoxon-Mann-Whitney U-test. In the OM tissue the mean contents of $\mathrm{Co}, \mathrm{Cr}, \mathrm{Fe}, \mathrm{Se}$, and $\mathrm{Zn}$ are respectively $1.8,1.7,1.8,1.7$, and 1.5 times higher than those in normal bone tissues. In the ES tissue the mean contents of Co, Fe, and Se are respectively 5.5, 17.1, and 18.6 times higher while the mean content of $\mathrm{Rb}$ is almost 2 times lower than in normal bone tissues. In ES tissue the mean contents of Fe and Se are significantly higher (9.3 and 10.5 times, respectively) and the mean content of $\mathrm{Rb}$ is more than 3 times lower than in inflamed bone. In addition, many inter-correlations between TE contents found in the control group were no longer evident in the inflamed and tumor transformed bone. Thus, considerable changes in TE content and their relationships were found in OM and ES and possible causes and effects of these alterations are discussed.
\end{abstract}

Keywords: Trace elements; Human bone; Osteomyelitis; Ewing's sarcoma; Neutron activation analysis

Abbreviations: OM: Osteomyelitis; ES: Ewing's Sarcoma; TE: Trace Elements; INAA: Instrumental Neutron Activation Analysis; INAA-LLR: INAA with High Resolution Spectrometry of Long-Lived Radionuclides; BSS: Biological Synthetic Standards; CRM: Certified Reference Material; SRM: Standard Reference Material; ROS: Reactive Oxygen Species

\section{Introduction}

Bone tumors are a heterogeneous group of tumors that all arise from bone tissue, which consists of cartilaginous, osteoid, osseous mineralized and fibrous tissue, and bone marrow elements. Each tissue can be subject to inflammation, benign or malignant tumors. Childhood bone cancer often is difficult to detect in its early stages because the associated signs and symptoms can be nonspecific, insidious in onset, and mimic more common disorders [1]. One of the most important differential diagnostics is between an inflammation and a malignant process such as Ewing's sarcoma.

Osteomyelitis (OM) is an inflammation of the bone and generally refers to a bacterial infection of bone [2]. OM occurs most commonly in children, and the overall prevalence is 1 case per 5000 children [3]. OM typically affects the most rapidly growing ends of long bones and is more common in the lower extremity, the metaphysis of the distal femur and of the proximal tibia being the most common sites of infection $[4,5]$.
Ewing's sarcoma (ES) is a primary bone malignancy that affects mainly children and adolescents. Overall, this malignancy is rare, with an annual incidence of approximately 2.9 cases per $100000[6,7]$. ES are typically found in the long bones of the legs and arms, or bones in the chest, trunk, pelvis, back, or head. [8]. All imaging methods such as conventional roentgenography, functional nuclear medicine including scintigraphy and positron emission tomography (PET), computed tomography (CT), and magnetic resonance imaging (MRI) are very important for the assessment of tumor location, shape, size, and infiltration of the adjacent tissue. However, clinical imaging is not useful as a routine examination in the diagnosis of ES for it may be confused with OM [3-10]. Definitive diagnosis must be achieved using biopsy and histopathologic evaluation. Thus, the goals of many investigations are to assist the clinician in making an appropriate diagnosis by providing a rational method of selecting non-traumatic diagnostic tests that maximize specificity and minimize costs. 


\section{Cancer Therapy \& Oncology International Journal}

It is well known that the tissues of human body differ greatly in their proportions of chemical elements and that there is the homeostasis of both bulk and trace element (TE) contents [11]. Our detailed previous studies have confirmed this using a chemical composition analysis of bone tissue [12-38]. Thus, it can be expected that normal bone, inflamed bone and bone tumors, possessing very different properties, have specific and different TE compositions. Moreover, as was shown by us in previous studies in vivo neutron activation analysis allows determination of some chemical element contents in intact bone, inflamed and malignant lesions of bone and has a potential to become a valuable diagnostic tool $[14,15,27,39]$.

To our knowledge, no data are available for the TE contents of $\mathrm{OM}$ and ES, to permit distinction between inflamed bone and malignant tumor. This work had three aims. The first was to obtain reliable data for silver (Ag), cobalt (Co), chromium (Cr), iron( $\mathrm{Fe}$ ), mercury (Hg), rubidium (Rb), antimony (Sb), selenium (Se), and zinc (Zn) contents in three groups of bone tissue samples - intact bone, OM and ES using non-destructive instrumental neutron activation analysis with high resolution spectrometry of longlived radionuclides (INAA-LLR). The second aim was to compare the TE contents in the different groups of samples and the third was to calculate inter-correlations between TE contents in each group of bone tissue samples. All studies were approved by the Ethical Committee of the Medical Radiological Research Center, Obninsk. All procedures performed in studies involving human participants were in accordance with the ethical standards of the institutional and/or national research committee and with the 1964 Helsinki declaration and its later amendments or comparable ethical standards.

\section{Material and Methods}

\section{Sample Preparation}

Forty-eight children, adolescents and adults were included in this study. The subjects were divided into three groups: control (1), OM (2) and ES (3). The reference/control group consisted of 27 persons with intact bone (12 females and 15 males, aged from 16 to 49 years) who had died from various non bone related causes, mainly unexpected from trauma. The intact bone samples mainly of femur and tibia were collected at the Department of Pathology, Obninsk City Hospital. Samples from 10 patients with OM ( 3 females and 7 males aged between 9 and 21 years) and 6 patients with ES ( 6 males, from 5 to 24 years old) were obtained from open biopsies or after operation from resected specimens. All patients with bone diseases were hospitalized at the Medical Radiological Research Centre. In all cases the diagnosis was confirmed by clinical and histological data.

A titanium tool was used to cut and to scrape samples [40,41]. All bone and tumor tissue samples were freeze dried, until constant mass was obtained, and homogenized. Then samples weighing about 50-100 mg were wrapped separately in highpurity aluminum foil washed with rectified alcohol beforehand and placed in a nitric acid-washed quartz ampoule.

\section{Instrumentation and Method}

To determine contents of the elements by comparison with a known standard, biological synthetic standards (BSS) prepared from phenol-formaldehyde resins and aliquots of commercial, chemically pure compounds were used. Corrected certified values of BSS element contents were reported by us earlier $[42,43]$. Ten certified reference material (CRM) IAEA H-5 (Animal Bone) sub-samples and ten standard reference material (SRM) NIST 1486 (Bone Meal) sub-samples weighing about 100 mg were analyzed in the same conditions as bone and tumor samples to estimate the precision and accuracy of the results.

A vertical channel of the WWR-c research nuclear reactor was applied to determine the mass fraction of $\mathrm{Ag}$, Co, Cr, Fe, $\mathrm{Hg}$, $\mathrm{Rb}, \mathrm{Sb}$, Se, and $\mathrm{Zn}$ by INAA-LLR. The quartz ampoule with bone samples, tumor samples, standards, CRM, and SRM was soldered, positioned in a transport aluminum container and exposed to a 100-hour neutron irradiation in a vertical channel with a thermal neutron flux about $10^{13} \mathrm{n} \cdot \mathrm{cm}^{-2} \cdot \mathrm{s}^{-1}$. Two months after irradiation the samples were reweighed and repacked. The duration of each measurement was from 1 to 10 hours. To reduce the high intensity of ${ }^{32} \mathrm{P} \beta$-particles $\left(\mathrm{T}_{1 / 2}=14.3 \mathrm{~d}\right)$ background, a berillium filter was used. A coaxial $98 \mathrm{~cm}^{3} \mathrm{Ge}$ (Li) detector and a spectrometric unit (NUC 8100, Hungary), including a PCcoupled multichannel analyzer, were used for measurements. The spectrometric unit provided $2.9 \mathrm{keV}$ resolution at the ${ }^{60} \mathrm{Co}$ $1332 \mathrm{keV}$ line. Information concerning the nuclear reactions, radionuclides and gamma-energies employed, together with other details of the analysis including the quality control of results were reported by us previously $[31,33,34,43]$.

\section{Computer Programs and Statistic}

A dedicated computer program of INAA mode optimization was used [44]. Using the Microsoft Office Excel software, the following quantities of statistics, arithmetic mean, standard deviation, standard error of mean, minimum and maximum values, median, percentiles with 0.025 and 0.975 levels were calculated for the TE mass fractions. The differences in the results between intact bone, $\mathrm{OM}$ and ES were evaluated using the parametric Student's t-test and non-parametric Wilcoxon-MannWhitney $U$-test. For the estimation of the Pearson correlation coefficient between different pairs of the TE mass fractions in each group of bone and tumor tissue samples the Microsoft Office Excel software was also used.

\section{Results}

Table 1 depicts our data for nine TE mass fractions determined by INAA-LLR in ten sub-samples of CRM IAEA H-5 Animal Bone and SRM NIST 1486 Bone Meal reference material and the certified values of this material. Table 2 presents certain statistical parameters (arithmetic mean, standard deviation, standard error of mean, minimal and maximal values, median, percentiles with 0.025 and 0.975 levels) of the $\mathrm{Ag}$, Co, $\mathrm{Cr}, \mathrm{Fe}, \mathrm{Hg}$, $\mathrm{Rb}, \mathrm{Sb}, \mathrm{Se}$, and $\mathrm{Zn}$ mass fractions in the samples of intact bone, 


\section{Cancer Therapy \& Oncology International Journal}

$\mathrm{OM}$ and ES. Information concerning the effect of inflammation (values of $r$-coefficient of correlation) including all pairs of the or malignant transformation on the TE mass fractions in bone is TE, identified by us in the samples of intact bone, OM and ES, are presented in Table 3 The data for inter-correlation calculations shown in Table 4.

Table 1: INAA data of trace elements of CRM IAEA H-5 Animal Bone and SRM NIST 1486 Bone Meal (mg/kg on dry weight basis).

\begin{tabular}{|c|c|c|c|c|c|c|}
\hline \multirow[t]{2}{*}{ Element } & \multicolumn{2}{|c|}{ CRM IAEA H-5 } & \multirow{2}{*}{$\begin{array}{c}\text { This work results } \\
\text { Mean } \pm \text { SD }\end{array}$} & \multicolumn{2}{|c|}{ SRM NIST 1486} & \multirow{2}{*}{$\begin{array}{c}\text { This work } \\
\text { results }\end{array}$} \\
\hline & Mean & Type & & Mean & Type & \\
\hline Ag & - & - & $<0.002 \mathrm{DL}$ & - & - & $<0.002 \mathrm{DL}$ \\
\hline Co & 0.25 & $\mathrm{~N}$ & $0.56 \pm 0.25$ & - & - & $0.11 \pm 0.02$ \\
\hline $\mathrm{Cr}$ & 2.56 & $\mathrm{~N}$ & $<0.8 \mathrm{DL}$ & - & - & $\leq 0.9$ \\
\hline $\mathrm{Fe}$ & $79 \pm 11$ & $\mathrm{C}$ & $85 \pm 17$ & $99 \pm 8$ & $\mathrm{C}$ & $93 \pm 11$ \\
\hline $\mathrm{Hg}$ & 0.008 & $\mathrm{~N}$ & $\leq 0.01$ & - & - & $\leq 0.01$ \\
\hline $\mathrm{Rb}$ & 1.07 & $\mathrm{~N}$ & $\leq 1.0$ & - & - & $\leq 0.9$ \\
\hline $\mathrm{Sb}$ & 0.024 & $\mathrm{~N}$ & $\leq 0.02$ & - & - & $\leq 0.02$ \\
\hline $\mathrm{Se}$ & 0.054 & $\mathrm{~N}$ & $\leq 0.05$ & 0.13 & $\mathrm{~N}$ & $\leq 0.05$ \\
\hline $\mathrm{Zn}$ & $89 \pm 15$ & $\mathrm{C}$ & $86 \pm 7$ & $147 \pm 16$ & $\mathrm{C}$ & $153 \pm 29$ \\
\hline
\end{tabular}

M: Arithmetic Mean; SD: Standard Deviation; C: Certified values; N: Non Certified values.

Table 2: Basic statistical parameters for Al, $\mathrm{Co}, \mathrm{Cr}, \mathrm{Fe}, \mathrm{Hg}, \mathrm{Rb}, \mathrm{Sb}, \mathrm{Se}$, and $\mathrm{Zn}$ mass fractions (mg/kg, dry mass basis) in tissue of normal bone, osteomyelitis and Ewing's sarcoma.

\begin{tabular}{|c|c|c|c|c|c|c|c|c|}
\hline Element & M & SD & SEM & Min & Max & Med & P0.025 & P0.975 \\
\hline \multicolumn{9}{|c|}{ Intact bone, n=27 } \\
\hline $\mathrm{Ag}$ & 0.00274 & 0.00152 & 0.00051 & 0.000256 & 0.00468 & 0.00282 & 0.000320 & 0.00458 \\
\hline Co & 0.0107 & 0.0070 & 0.0014 & 0.00370 & 0.0345 & 0.00785 & 0.00464 & 0.0288 \\
\hline $\mathrm{Cr}$ & 0.274 & 0.182 & 0.057 & 0.110 & 0.669 & 0.202 & 0.117 & 0.629 \\
\hline $\mathrm{Fe}$ & 51.2 & 46.3 & 9.3 & 9.20 & 173 & 30.2 & 9.68 & 155 \\
\hline $\mathrm{Hg}$ & 0.0057 & 0.0044 & 0.0014 & 0.00100 & 0.0138 & 0.00525 & 0.00100 & 0.0133 \\
\hline $\mathrm{Rb}$ & 3.68 & 1.58 & 0.48 & 0.970 & 6.57 & 3.30 & 1.40 & 6.41 \\
\hline $\mathrm{Sb}$ & 0.0151 & 0.0102 & 0.0032 & 0.00600 & 0.0420 & 0.0139 & 0.00600 & 0.0364 \\
\hline $\mathrm{Se}$ & 0.176 & 0.092 & 0.029 & 0.0550 & 0.358 & 0.169 & 0.0633 & 0.336 \\
\hline $\mathrm{Zn}$ & 80.6 & 15.4 & 3.0 & 45.4 & 115 & 82.1 & 51.7 & 109 \\
\hline \multicolumn{9}{|c|}{ Osteomyelitis, $n=10$} \\
\hline $\mathrm{Ag}$ & 0.00360 & 0.00130 & 0.00041 & 0.00076 & 0.00560 & 0.00355 & 0.00124 & 0.00548 \\
\hline Co & 0.0190 & 0.0092 & 0.0029 & 0.00300 & 0.0376 & 0.0179 & 0.00503 & 0.0353 \\
\hline $\mathrm{Cr}$ & 0.457 & 0.151 & 0.048 & 0.246 & 0.741 & 0.438 & 0.260 & 0.705 \\
\hline $\mathrm{Fe}$ & 94 & 37 & 12 & 45.9 & 182 & 94 & 48.3 & 165 \\
\hline $\mathrm{Hg}$ & 0.0101 & 0.0053 & 0.0017 & 0.00210 & 0.0200 & 0.0105 & 0.00239 & 0.0185 \\
\hline $\mathrm{Rb}$ & 4.39 & 2.30 & 0.73 & 0.520 & 7.98 & 4.22 & 0.734 & 7.71 \\
\hline $\mathrm{Sb}$ & 0.0237 & 0.0188 & 0.0059 & 0.00770 & 0.0680 & 0.0166 & 0.00822 & 0.0624 \\
\hline $\mathrm{Se}$ & 0.310 & 0.155 & 0.049 & 0.130 & 0.610 & 0.260 & 0.137 & 0.588 \\
\hline $\mathrm{Zn}$ & 122.2 & 15.4 & 4.9 & 97.8 & 144 & 122 & 99.2 & 143 \\
\hline \multicolumn{9}{|c|}{ Ewing's sarcoma, $n=6$} \\
\hline $\mathrm{Ag}$ & 0.0027 & 0.0031 & 0.0013 & 0.000200 & 0.00850 & 0.00155 & 0.000260 & 0.00788 \\
\hline Co & 0.059 & 0.050 & 0.020 & 0.0140 & 0.129 & 0.0405 & 0.0146 & 0.127 \\
\hline $\mathrm{Cr}$ & 0.338 & 0.218 & 0.089 & 0.0200 & 0.628 & 0.360 & 0.0419 & 0.608 \\
\hline $\mathrm{Fe}$ & 878 & 484 & 198 & 228 & 1497 & 803 & 270 & 1482 \\
\hline $\mathrm{Hg}$ & 0.0152 & 0.0174 & 0.0071 & 0.000560 & 0.0402 & 0.00670 & 0.000823 & 0.0395 \\
\hline
\end{tabular}




\section{Cancer Therapy \& Oncology International Journal}

\begin{tabular}{|c|c|c|c|c|c|c|c|c|}
\hline $\mathrm{Rb}$ & 1.32 & 0.83 & 0.34 & 0.170 & 2.49 & 1.38 & 0.235 & 2.41 \\
\hline $\mathrm{Sb}$ & 0.0176 & 0.0230 & 0.0094 & 0.000100 & 0.0634 & 0.0111 & 0.000725 & 0.0573 \\
\hline $\mathrm{Se}$ & 3.27 & 2.85 & 1.16 & 0.608 & 8.66 & 2.22 & 0.776 & 8.07 \\
\hline $\mathrm{Zn}$ & 131 & 79 & 32 & 21.3 & 226 & 125 & 28.2 & 225 \\
\hline
\end{tabular}

M: Arithmetic Mean, SD: Standard Deviation; SEM: Standard Error of Mean, Min: Minimum Value; Max: Maximum Value; Med: Median; P0.025: Percentile with 0.025 level; P0.975: Percentile with 0.975 level.

Table 3: Differences between mean values (M $\pm \mathrm{SEM}$ ) of $\mathrm{Al}, \mathrm{Co}, \mathrm{Cr}, \mathrm{Fe}, \mathrm{Hg}, \mathrm{Rb}, \mathrm{Sb}$, Se, and $\mathrm{Zn}$ mass fractions (mg/kg, dry mass basis) in tissue of normal bone, osteomyelitis and Ewing's sarcoma.

\begin{tabular}{|c|c|c|c|c|c|c|}
\hline $\begin{array}{l}\text { Groups of } \\
\text { samples }\end{array}$ & Element & Normal (N) & $\begin{array}{c}\text { Osteomyelitis } \\
\text { (OM) }\end{array}$ & t-test $p \leq$ & U-test p & Ratio OM/N \\
\hline \multirow{9}{*}{$\begin{array}{l}\text { Osteomyelitis and } \\
\text { Normal }\end{array}$} & $\mathrm{Ag}$ & $0.00274 \pm .00051$ & $0.00360 \pm 0.00041$ & 0.181 & $>0.05$ & 1.31 \\
\hline & Co & $0.0107 \pm 0.0014$ & $0.0190 \pm 0.0029$ & 0.023 & $\leq \mathbf{0 . 0 1}$ & 1.78 \\
\hline & $\mathrm{Cr}$ & $0.274 \pm 0.057$ & $0.457 \pm 0.048$ & 0.025 & $\leq \mathbf{0 . 0 1}$ & 1.67 \\
\hline & $\mathrm{Fe}$ & $51.2 \pm 9.3$ & $94 \pm 12$ & 0.009 & $\leq \mathbf{0 . 0 1}$ & 1.84 \\
\hline & $\mathrm{Hg}$ & $0.0057 \pm 0.0014$ & $0.0101 \pm 0.0017$ & 0.062 & $>0.05$ & 1.77 \\
\hline & $\mathrm{Rb}$ & $3.68 \pm 0.48$ & $4.39 \pm 0.73$ & 0.436 & $>0.05$ & 1.19 \\
\hline & $\mathrm{Sb}$ & $0.0151 \pm 0.0032$ & $0.0237 \pm 0.0059$ & 0.225 & $>0.05$ & 1.57 \\
\hline & Se & $0.176 \pm 0.029$ & $0.310 \pm 0.049$ & 0.032 & $\leq \mathbf{0 . 0 1}$ & 1.76 \\
\hline & $\mathrm{Zn}$ & $80.6 \pm 3.0$ & $122.2 \pm 4.9$ & 0.00002 & $\leq \mathbf{0 . 0 1}$ & 1.52 \\
\hline Groups of samples & Element & Norm $(\mathrm{N})$ & $\begin{array}{l}\text { Ewing's sarcoma } \\
\text { (ES) }\end{array}$ & $\mathrm{t}$-test $\mathrm{p} \leq$ & U-test $p$ & Ratio ES/N \\
\hline \multirow{9}{*}{$\begin{array}{l}\text { Ewing's sarcoma } \\
\text { and Normal }\end{array}$} & $\mathrm{Ag}$ & $0.00274 \pm .00051$ & $0.0027 \pm 0.0013$ & 0.951 & $>0.05$ & 0.99 \\
\hline & Co & $0.0107 \pm 0.0014$ & $0.059 \pm 0.020$ & 0.065 & $\leq \mathbf{0 . 0 1}$ & 5.51 \\
\hline & $\mathrm{Cr}$ & $0.274 \pm 0.057$ & $0.338 \pm 0.089$ & 0.560 & $>0.05$ & 1.23 \\
\hline & $\mathrm{Fe}$ & $51.2 \pm 9.3$ & $878 \pm 198$ & 0.009 & $\leq \mathbf{0 . 0 1}$ & 17.1 \\
\hline & $\mathrm{Hg}$ & $0.0057 \pm 0.0014$ & $0.0152 \pm 0.0071$ & 0.243 & $>0.05$ & 2.67 \\
\hline & $\mathrm{Rb}$ & $3.68 \pm 0.48$ & $1.32 \pm 0.34$ & 0.001 & $\leq \mathbf{0 . 0 1}$ & 0.36 \\
\hline & $\mathrm{Sb}$ & $0.0151 \pm 0.0032$ & $0.0176 \pm 0.0094$ & 0.812 & $>0.05$ & 1.17 \\
\hline & Se & $0.176 \pm 0.029$ & $3.27 \pm 1.16$ & 0.045 & $\leq \mathbf{0 . 0 1}$ & 18.6 \\
\hline & $\mathrm{Zn}$ & $80.6 \pm 3.0$ & $131 \pm 32$ & 0.176 & $>0.05$ & 1.63 \\
\hline Groups of samples & Element & $\begin{array}{l}\text { Osteomyelitis } \\
\text { (OM) }\end{array}$ & $\begin{array}{l}\text { Ewing's sarcoma } \\
\text { (ES) }\end{array}$ & t-test $\mathrm{p} \leq$ & U-test $p$ & Ratio ES/ OM \\
\hline \multirow{9}{*}{$\begin{array}{l}\text { Ewing's sarcoma } \\
\text { and Osteomyelitis }\end{array}$} & Ag & $0.00360 \pm 0.00041$ & $0.0027 \pm 0.0013$ & 0.505 & $>0.05$ & 0.75 \\
\hline & Co & $0.0190 \pm 0.0029$ & $0.059 \pm 0.020$ & 0.109 & $>0.05$ & 3.11 \\
\hline & $\mathrm{Cr}$ & $0.457 \pm 0.048$ & $0.338 \pm 0.089$ & 0.272 & $>0.05$ & 0.74 \\
\hline & $\mathrm{Fe}$ & $94 \pm 12$ & $878 \pm 198$ & 0.011 & $\leq \mathbf{0 . 0 1}$ & 9.34 \\
\hline & $\mathrm{Hg}$ & $0.0101 \pm 0.0017$ & $0.0152 \pm 0.0071$ & 0.510 & $>0.05$ & 1.50 \\
\hline & $\mathrm{Rb}$ & $4.39 \pm 0.73$ & $1.32 \pm 0.34$ & 0.005 & $\leq \mathbf{0 . 0 1}$ & 0.30 \\
\hline & $\mathrm{Sb}$ & $0.0237 \pm 0.0059$ & $0.0176 \pm 0.0094$ & 0.597 & $>0.05$ & 0.74 \\
\hline & $\mathrm{Se}$ & $0.310 \pm 0.049$ & $3.27 \pm 1.16$ & 0.052 & $\leq \mathbf{0 . 0 1}$ & 10.5 \\
\hline & $\mathrm{Zn}$ & $122.2 \pm 4.9$ & $131 \pm 32$ & 0.791 & $>0.05$ & 1.07 \\
\hline
\end{tabular}

M: Arithmetic Mean; SEM: Standard Error of mean, t-test - Parametric Student's t-test, U-test - non-parametric Wilcoxon-Mann-Whitney test statistically significant values are in bold. 


\section{Cancer Therapy \& Oncology International Journal}

Table 4: Intercorrelations of pairs of the trace element mass fractions in tissue of normal bone, osteomyelitis and Ewing's sarcoma.

\begin{tabular}{|c|c|c|c|c|c|c|c|c|c|}
\hline Tissue & Element & Co & $\mathrm{Cr}$ & $\mathrm{Fe}$ & $\mathrm{Hg}$ & $\mathbf{R b}$ & Sb & Se & Zn \\
\hline Intact & $\mathrm{Ag}$ & -0.23 & 0.51 & $-0.80^{\mathrm{b}}$ & -0.02 & $0.62^{\mathrm{a}}$ & 0.31 & -0.45 & 0.38 \\
\hline \multirow{8}{*}{ Bone } & Co & 1.00 & 0.16 & $0.55^{\mathrm{a}}$ & $0.79^{\mathrm{b}}$ & -0.10 & 0.08 & 0.52 & 0.17 \\
\hline & $\mathrm{Cr}$ & 0.16 & 1.00 & -0.48 & 0.51 & $0.56^{\mathrm{a}}$ & -0.31 & -0.08 & 0.46 \\
\hline & $\mathrm{Fe}$ & $0.55^{\mathrm{a}}$ & -0.48 & 1.00 & 0.09 & -0.54 & -0.25 & $0.60^{\mathrm{a}}$ & -0.17 \\
\hline & $\mathrm{Hg}$ & $0.79^{\mathrm{b}}$ & 0.51 & 0.09 & 1.00 & 0.18 & -0.13 & 0.35 & -0.14 \\
\hline & $\mathrm{Rb}$ & -0.10 & $0.56^{\mathrm{a}}$ & -0.54 & 0.18 & 1.00 & -0.05 & -0.06 & 0.34 \\
\hline & $\mathrm{Sb}$ & 0.08 & -0.31 & -0.25 & -0.13 & -0.05 & 1.00 & 0.04 & 0.22 \\
\hline & Se & 0.52 & -0.08 & $0.60^{\mathrm{a}}$ & 0.35 & -0.06 & 0.04 & 1.00 & 0.24 \\
\hline & Zn & 0.17 & 0.46 & -0.17 & -0.14 & 0.34 & 0.22 & 0.24 & 1.00 \\
\hline \multirow{9}{*}{ Osteomyelitis } & $\mathrm{Ag}$ & 0.45 & 0.16 & 0.33 & $0.71^{\mathrm{a}}$ & 0.37 & 0.16 & 0.07 & $-0.78^{b}$ \\
\hline & Co & 1.00 & 0.28 & $-0.74^{\mathrm{a}}$ & 0.49 & -0.17 & 0.22 & 0.43 & -0.43 \\
\hline & $\mathrm{Cr}$ & 0.28 & 1.00 & -0.22 & -0.25 & -0.43 & 0.08 & -0.53 & -0.28 \\
\hline & $\mathrm{Fe}$ & $-0.74^{a}$ & -0.22 & 1.00 & 0.48 & $0.56^{\mathrm{a}}$ & -0.11 & $-0.70^{\mathrm{a}}$ & -0.24 \\
\hline & $\mathrm{Hg}$ & 0.49 & -0.25 & 0.48 & 1.00 & $0.63^{\mathrm{a}}$ & 0.30 & 0.45 & $-0.57^{a}$ \\
\hline & $\mathrm{Rb}$ & -0.17 & -0.43 & $0.56^{\mathrm{a}}$ & $0.63^{\mathrm{a}}$ & 1.00 & -0.12 & 0.21 & -0.12 \\
\hline & $\mathrm{Sb}$ & 0.22 & 0.08 & -0.11 & 0.30 & -0.12 & 1.00 & 0.01 & 0.16 \\
\hline & $\mathrm{Se}$ & 0.43 & -0.53 & $-0.70^{\mathrm{a}}$ & 0.45 & 0.21 & 0.01 & 1.00 & -0.12 \\
\hline & $\mathrm{Zn}$ & -0.43 & -0.28 & -0.24 & $-0.57^{a}$ & -0.12 & 0.16 & -0.12 & 1.00 \\
\hline \multirow[t]{9}{*}{$\begin{array}{l}\text { Ewing's } \\
\text { sarcoma }\end{array}$} & $\mathrm{Ag}$ & -0.31 & $-0.71^{a}$ & -0.54 & $0.67^{\mathrm{a}}$ & 0.44 & -0.03 & $-0.85^{b}$ & -0.20 \\
\hline & Co & 1.00 & -0.06 & 0.42 & 0.23 & 0.08 & $0.81^{\mathrm{a}}$ & $0.80^{\mathrm{a}}$ & 0.39 \\
\hline & $\mathrm{Cr}$ & -0.06 & 1.00 & 0.52 & -0.42 & 0.01 & 0.12 & 0.24 & 0.46 \\
\hline & $\mathrm{Fe}$ & 0.42 & 0.52 & 1.00 & -0.09 & 0.45 & 0.50 & 0.43 & 0.07 \\
\hline & $\mathrm{Hg}$ & 0.23 & -0.42 & -0.09 & 1.00 & $0.74^{\mathrm{a}}$ & 0.59 & -0.65 & 0.42 \\
\hline & $\mathrm{Rb}$ & 0.08 & 0.01 & 0.45 & $0.74^{\mathrm{a}}$ & 1.00 & 0.60 & $-0.85^{b}$ & 0.22 \\
\hline & $\mathrm{Sb}$ & $0.81^{a}$ & 0.12 & 0.50 & 0.59 & 0.60 & 1.00 & 0.17 & 0.56 \\
\hline & $\mathrm{Se}$ & $0.80^{\mathrm{a}}$ & 0.24 & 0.43 & -0.65 & $-0.85^{\mathrm{b}}$ & 0.17 & 1.00 & 0.03 \\
\hline & $\mathrm{Zn}$ & 0.39 & 0.46 & 0.07 & 0.42 & 0.22 & 0.56 & 0.03 & 1.00 \\
\hline
\end{tabular}

Statistically significant difference: ${ }^{a}-p \leq 0.05,{ }^{b}-p \leq 0.01,{ }^{c}-p \leq 0.001$.

\section{Discussion}

The non-destructive INAA-LLR was used in this research study because this method has many definite advantages over other analytical methods, particularly, in the clinical chemistry. For example, after non-destructive INAA-LLR there is a possibility to check the results for some TE and to receive additional information about other TE contents by destructive analytical methods such as atomic absorption spectrometry, inductively coupled plasma atomic emission spectrometry, inductively coupled plasma mass spectrometry and so on, using the same bone samples. Moreover, if a deep-cooled channel of nuclear reactor is available, the non-destructive INAA-LLR allows determining TE contents in the fresh bone/tumor samples and combining TE study with histological investigation. It is also necessary to keep in mind that the non-destructive methods are the current gold-standard solution to control destructive analytical techniques [11]. The destructive analytical methods are based on measurements of processed tissue. In such studies tissue samples are ashed and/or acid digested before analysis. There is evidence that certain quantities of TE are lost as a result of such treatment $[11,41,45]$. There is no doubt that every method available for the measurement of TE contents in bone and tumor samples can be used. However, when using destructive analytical methods it is necessary to control for the losses of TE, for complete acid digestion of the sample, and for the contaminations by TE during sample decomposition, which needs adding some chemicals.

The results of mean values for Fe and $\mathrm{Zn}$ - two representative TE of CRM IAEA H-5 (Animal Bone) and SRM NIST1486 (Bone Meal) were in the range of $95 \%$ confidence interval $(M \pm 2 S D)$ of the certificates' values (Table 1). Good agreement with the certified data of CRM and SRM for Fe and Zn mass fractions determined by INAA-LLR indicate an acceptable accuracy and for other TE mass fractions obtained in the study of intact, inflamed bone and tumor tissue samples presented in Tables 2-4. 


\section{Cancer Therapy \& Oncology International Journal}

The mean values and all selected statistical parameters were calculated for nine TE (Ag, Co, Cr, Fe, Hg, Rb, Sb, Se, and $\mathrm{Zn}$ ) mass fractions in normal bone, OM and ES samples (Table 2). From Table 3 it is observed that in the OM tissue the mean mass fractions of $\mathrm{Co}, \mathrm{Cr}$, Fe, Se, and $\mathrm{Zn}$ are respectively 1.8, 1.7, 1.8, 1.7, and 1.5 times higher than those in normal bone tissues. In the ES tissue the mean mass fractions of $\mathrm{Co}, \mathrm{Fe}$, and Se are respectively $5.5,17.1$, and 18.6 times higher while the mean mass fraction of $\mathrm{Rb}$ is almost 2 times lower than in normal bone tissues. In ES tissue the mean mass fractions of Fe and Se are significantly higher ( 9.3 and 10.5 times, respectively) and the mean mass fraction of $\mathrm{Rb}$ is more than 3 times lower than in inflamed bone.

In the control group a statistically significant direct correlation was found between the Ag and $\mathrm{Rb}(\mathrm{r}=0.62, \mathrm{p} \leq 0.05)$, Co and Fe ( $r=0.55, p \leq 0.05)$, Co and Hg ( $r=0.79, p \leq 0.01)$, Cr and $\mathrm{Rb}(\mathrm{r}=0.56, \mathrm{p} \leq 0.05)$, and between Fe and Se ( $\mathrm{r}=0.60$, p $\leq 0.05$ ) mass fractions (Table 4 ). In the same group a pronounced inverse correlation was observed between the Fe and $\mathrm{Ag}(\mathrm{r}=$ $0.80, \mathrm{p} \leq 0.01$ ). If some positive correlations between the TE were predictable (e.g., Fe-Co), the interpretation of other observed relationships requires further study for a more complete understanding. In the OM tissue many significant correlations between TE found in the control group are no longer evident (Table 4). For example, direct correlation between Fe and Co or between $\mathrm{Fe}$ and Se are transformed in inverse correlations. Moreover, other direct correlations between $\mathrm{Ag}$ and $\mathrm{Hg}, \mathrm{Fe}$ and $\mathrm{Rb}, \mathrm{Hg}$ and $\mathrm{Rb}$, as well as inverse correlations between $\mathrm{Ag}$ and $\mathrm{Zn}$, and also between $\mathrm{Hg}$ and $\mathrm{Zn}$ were observed (Table 4).

Similarly, in the ES tissue many significant correlations between TE found in the control group are also no longer evident, for example, direct correlation between Fe and Co or between Fe and Se, etc. (Table 4). However, direct correlations between $\mathrm{Ag}$ and $\mathrm{Hg}$, $\mathrm{Co}$ and $\mathrm{Sb}$, Co and $\mathrm{Se}$, and also $\mathrm{Hg}$ and $\mathrm{Rb}$, as well as inverse correlations between $\mathrm{Ag}$ and $\mathrm{Cr}, \mathrm{Ag}$ and $\mathrm{Se}$, and also $\mathrm{Rb}$ and Se were observed (Table 4). Thus, if we accept the levels and relationships of TE mass fraction in the intact bone samples of control group as a norm, we have to conclude that with inflammation and neoplasm the levels and relationships of TE in bone significantly change. No published data referring to contents of TE or correlations between TE mass fractions in the $\mathrm{OM}$ and ES of bone were found.

Characteristically, elevated or reduced levels of TE observed in inflamed or neoplasms tissues are discussed in terms of their potential role in the initiation and promotion of inflammation or tumor. In other words, using the low or high levels of the TE in inflamed and malignant lesions of tissue researchers try to determine the carcinogenic role of the deficiency or excess of each TE in investigated organ. In our opinion, abnormal levels of many TE in inflamed tissue or tumor could be and cause, and also effect of benign or malignant transformation. From the results of such kind studies, it is not always possible to decide whether the measured decrease or increase in TE level in pathologically altered tissue is the reason for alterations or vice versa.
Bone is a mineralized connective tissue. It is formed by osteoblasts, that deposit collagen and release $\mathrm{Ca}, \mathrm{Mg}$, and phosphate ions that combine chemically within the collagenous matrix into a crystalline mineral, known as bone hydroxyapatite. On average, bone tissue contains about 10-25\% water, $25 \%$ protein fibers like collagen, and $50 \%$ hydroxyapatite $\mathrm{Ca}_{10}\left(\mathrm{PO}_{4}\right)_{6}(\mathrm{OH})_{2}$. Many TE are bone-seeking elements and they are closely associated with hydroxyapatite [33,34,37]. ES is classified as a bone tumor. Our previous findings showed that the means of the Ca and $\mathrm{P}$ mass fraction in the ES tissue are lower than in normal or inflamed bone, but the mean of $\mathrm{Ca} / \mathrm{P}$ ratio is similar $[46,47]$. It suggested that ES continues to form bone hydroxyapatite but to a lesser degree than normal bone.

\section{Cobalt}

Health effects of high exposure to Co, whether resulting from occupational, environmental, dietary and medical contact are characterized by a complex clinical syndrome, including mainly neurological, cardiovascular and endocrine deficits $[48,49]$. Co is genotoxic and carcinogenic. This is mainly caused by oxidative DNA damage by reactive oxygen species (ROS), perhaps combined with inhibition of DNA repair [50]. Indeed, Co ions affect osteoblast proliferation, size, and shape. Co ions also promote secretion of cytokines from osteoblasts, which leads to inflammation and osteoclast differentiation, maturation, and stimulation [51]. Thus, an inflammatory and neoplastic effect of elevated Co level in OM and ES tissue may be assumed. It was found in the present study, that there is a direct correlation between Fe and Co levels in normal bone (Table 4). Therefore an increased level of Co in both OM and ES is closely connected to a high Fe content in inflamed and, particularly, in tumor tissue (Table 3). Anyway, the accumulation of Co in OM and ES tissue could possibly be explored as a diagnostic marker for these, inflamed bone diseases.

\section{Chromium}

Cr-compounds are cytotoxic, genotoxic, and carcinogenic in nature. Some $\mathrm{Cr}$ forms, including hexavalent chromium $\left(\mathrm{Cr}^{6+}\right)$, are toxicants known for their carcinogenic effect in humans. The lung cancer risk is prevalent in pigment chromate handlers, ferrochromium production workers, stainless steel welders, and chromeplaters [52]. Except in Cr-related industries and associated environments, $\mathrm{Cr}$ intoxication from environmental exposure is not common. However, it was found, that drinking water supplies in many geographic areas contain chromium in the +3 and +6 oxidation states. Exposure of animals to $\mathrm{Cr}^{6+}$ in drinking water induced tumors in the alimentary tract, with linear and supralinear responses in the mouse small intestine [53]. Many other animal experiments and in vitro studies demonstrate also that $\mathrm{Cr}$ can induce oxidative stress and exert cytotoxic effects [54]. Besides ROS generation, oxidative stress, and cytotoxic effects a variety of other changes like DNA damage, increased formation of DNA adducts and DNA-protein cross-links, DNA strand breaks, chromosomal aberrations and instability, disruption of mitotic cell division, chromosomal 


\section{Cancer Therapy \& Oncology International Journal}

aberration, premature cell division, S or G2/M cell cycle phase arrest, and carcinogenesis also occur in humans or experimental test systems [52]. Thus, at least an inflammatory effect of elevated $\mathrm{Cr}$ level in OM may be assumed.

Iron: Our findings show that the mean of the Fe mass fractions in the OM and ES tissue samples were respectively 1.8 and 17.1 times greater than in normal bone tissues (Table 3). It is well known that the Fe mass fraction in a tissue sample depends mainly on the blood volume in that tissue. Thus, one can speculate that $\mathrm{OM}$ and, particularly, ES are characterized by an increase of the mean values of the Fe mass fractions because their levels of vascularization are higher than that of normal bone. Moreover, one can deduce that the level of ES vascularization is higher than that of inflamed bone. Thus, this difference could possibly be explored to aid the diagnosis of bone malignancy.

\section{Rubidium}

There is very little information about the effects of $\mathrm{Rb}$ in organisms. No negative environmental effects have been reported. $\mathrm{Rb}$ is only slightly toxic on an acute toxicological basis and would pose an acute health hazard only when ingested in large quantities [55]. $\mathrm{Rb}$ has some function in immune responce [56], probably by supporting cell differentiation [57]. The reason for a lower level of $\mathrm{Rb}$ in ES tissue than that in normal and inflamed bone is not completely understood and requires further studies. However, a significantly lower Rb level in ES in comparison with that in OM could possibly be explored to aid the diagnosis of bone malignancy.

\section{Selenium}

In the both $\mathrm{OM}$ and ES tissue the mean Se mass fractions were more than 10 times higher than in normal bone (Table 3). A high Se level was reported in malignant tumors of the ovary [58], lung [59], prostate [60-68], breast [69,70], gastro intestinal tract [71], and also in cancers of the stomach [72] and thyroid [73]. Moreover, in our previous study elevated levels of Se were found in such malignant tumors of bone as osteogenic sarcoma [74], chondrosarcoma [75], and malignant giant cell tumor of bone [76]. The role played by Se in those tumors remains unknown, but in general it is accepted that certain proteins containing Se can mediate the protective effects against oxidative stress. A literature-based analysis found the association of malignant tissue transformation with local oxidative stress. Studies have shown that oxidative stress conditions play an important role in both the initiation and the progression of cancer by regulating molecules such as DNA, enhancers, transcription factors, and cell cycle regulators [77]. However the cause of increased Se in $\mathrm{OM}$ and particularly in ES of bone is not completely understood and requires further studies. Anyway, the great difference in accumulation of Se between OM and ES tissue could possibly be explored to aid the diagnosis of malignant tumor.

\section{Zinc}

$\mathrm{Zn}$ is active in more than 300 proteins and over 100 DNAbinding proteins, including the tumor suppressor protein $\mathrm{p} 53$, a Zn-binding transcription factor acting as a key regulator of cell growth and survival after various forms of cellular stress. p53 is mutated in half of human tumors and its activity is tightly regulated by metals and redox mechanisms. $\mathrm{Zn}$ ions are cofactors of the superoxide dismutase enzymes, which prevent the onset and progression of tumors through cell protection against substances that cause the formation of free radicals and reactive oxygen species. The role of zinc is to act as a membrane stabilizer and to participate in antioxidative protection and oxidative stress inhibition.

A low level of $\mathrm{Zn}$ was reported in malignant tumors of liver $[78,79,80]$, kidney [78], uterus [81], lung [80,82], prostate [60$67,80,83-86]$, stomach [87], testis [87], thyroid [72,80,86,87] and in esophageal squamous cell cancer [88]. These facts imply that reduced $\mathrm{Zn}$ content in tumors is probably one of the factors in the etiology of malignant transformation of different tissues, because $\mathrm{Zn}$ deficiency has been linked to severe deficiency in immune function and disruption in T-Cell function. Zn deficiency also causes inactivation of p53, a tumor suppressor protein, which has been associated with many cancers [87]. But, OM and ES tissues are characterized by slightly higher level of $\mathrm{Zn}$ than that in normal bone. The cause of $\mathrm{Zn}$ accumulation by $\mathrm{OM}$ and ES tissue is not completely understood and requires further studies. However, it is well known that not only $\mathrm{Zn}$ deficiency but also excess of this metal may be deleterious and involved in the etiology of inflammation and malignant transformation of different tissues [89]. Thus, it seems that the window of optimal Zn level in different tissues, including bone, is quite narrow.

Trace element inter-correlations: Each of the TE is distinct in its primary mode of action. Moreover, there are several forms of synergistic action of the TE as a part of intracellular metabolism, during which several reactive intermediates and byproducts are created [90-92]. These reactive species are capable of potent and surprisingly selective activation of stress-signaling pathways, inhibition of DNA metabolism, repair, and formation of DNA crosslink's, which are known to contribute to the development of human cancers $[91,93]$. Thus, in addition to TE contents changes of TE relationships (inter-correlations) might be involved in etiology and pathophysiology of bone inflammation and tumors.

\section{Limitations}

This study has several limitations. Firstly, analytical techniques employed in this study measure only nine TE (Ag, Co, $\mathrm{Cr}, \mathrm{Fe}, \mathrm{Hg}, \mathrm{Rb}, \mathrm{Sb}, \mathrm{Se}$, and $\mathrm{Zn}$ ) mass fractions. There are many other TE associated with different levels of oxidative stress and carcinogenesis. Thus, future studies should be directed toward using other analytical methods which will extend the list of TE investigated in normal bone as well as in the OM and ES of bone. Secondly, the sample size of OM and ES groups was relatively small. Despite these limitations, this study provides evidence that the levels of $\mathrm{Co}, \mathrm{Cr}, \mathrm{Fe}, \mathrm{Rb}$, Se, and $\mathrm{Zn}$ mass fractions have altered in $\mathrm{OM}$ and ES tissue and shows the necessity to continue TE research of these diseases of bone. 


\section{Cancer Therapy \& Oncology International Journal}

\section{Conclusion}

INAA-LLR is a most satisfactory analytical tool to determine non-destructively the elemental content of $\mathrm{Ag}$, $\mathrm{Co}, \mathrm{Cr}, \mathrm{Fe}, \mathrm{Hg}$, $\mathrm{Rb}, \mathrm{Sb}, \mathrm{Se}$, and $\mathrm{Zn}$ in samples of human intact bone and also in samples of OM and ES. In the OM tissue the mean mass fractions of $\mathrm{Co}, \mathrm{Cr}, \mathrm{Fe}, \mathrm{Se}$, and $\mathrm{Zn}$ are respectively $1.8,1.7,1.8,1.7$, and 1.5 times higher than those in normal bone tissues. In the ES tissue the mean mass fractions of $\mathrm{Co}, \mathrm{Fe}$, and Se are respectively 5.5, 17.1 , and 18.6 times higher while the mean mass fraction of $\mathrm{Rb}$ is almost 2 times lower than in normal bone tissues. In ES tissue the mean mass fractions of Fe and Se are significantly higher (9.3 and 10.5 times, respectively) and the mean mass fraction of $\mathrm{Rb}$ is more than 3 times lower than in inflamed bone. In addition, many inter-correlations between TE contents found in the control group were no longer evident in the inflamed and tumor transformed bone. Thus, if we accept the levels and relationships of TE mass fraction in the intact bone as a norm, we have to conclude that in OM and ES tissues the TE homeostasis was significantly disturbed.

The studies on the role of TE in the etiology and pathogenesis of OM and ES should be continued, because of the limitations of numbers of different TEs studied in this work and to determine relevant mechanisms which may explain the findings. This paper has only considered two specific bone diseases. However the value of this approach to the determination of the inflamed and malignant lesions of bone using TE analysis has been confirmed. It is likely to have many other useful applications and deserves to be included in the diagnostician's armamentarium after appropriate experimental confirmation.

\section{Acknowledgement}

We are grateful to the late Prof. V.A. Bizer, Medical Radiological Research Center, Obninsk, for supplying GCT tissue samples.

\section{References}

1. Linabery AM, Ross JA (2008) Trends in childhood cancer incidence in the U.S. (1992-2004). Cancer 112(2): 416-432.

2. De Boeck H (2005) Osteomyelitis and septic arthritis in children. Acta Orthop Belg 71: 505-515.

3. McCarthy JJ, Dormans JP, Kozin SH, Pizzutillo PD (2004) Musculoskeletal infections in children. Basic treatment principles and recent advancements. J Bone Joint Surg 86-A: 850-863.

4. Hankin D, Bowling FL, Metcalfe SA, Whitehouse RA, Boulton AJ (2011) Critically evaluating the role of diagnostic imaging in osteomyelitis. Foot Ankle Spec 4(2): 100-105.

5. Van Schuppen J, van Doorn MM, van Rijn RR (2012) Childhood osteomyelitis: imaging characteristics. Insights Imaging 3: 519-533.

6. Esiashvili N, Goodman M, Marcus RB Jr (2008) Changes in incidence and survival of Ewing sarcoma patients over the past 3 decades: Surveillance Epidemiology and End Results data. J Pediatr Hematol Oncol 30(6): 425-430.

7. Balamuth NJ, Womer RB (2010) Ewing's Sarcoma. Lancet Oncol 11(2): 184-192.

8. Maheshwari AV, Cheng EY (2010) Ewing sarcoma family of tumors. J Am Acad Orthop Surg 18(2): 94-107.
9. Peersman B, Vanhoenacker FM, Heyman S, Van Herendael B, Stam M, et al. (2007) Ewing's sarcoma: imaging features. JBR-BTR 90(50): 368376.

10. Henninger B, Glodny B, Rudisch A, Trieb T, Loizides A, et al. (2013) Ewing sarcoma versus osteomyelitis: differential diagnosis with magnetic resonance imaging. Skeletal Radiol 42(8): 1097-1104.

11. Zaichick V (2006) Medical elementology as a new scientific discipline. J Radioanal Nucl Chem 269(2): 303-309.

12. Zherbin EA, Zaichick V (1976) Several aspects of applied neutron activation in medicine: The present state and development of activation analysis in the Institute of Medical Radiology. In: Proceedings of the $2^{\text {nd }}$ Meeting on New Nuclear-Physical Methods Used in Solving ScientificTechnical and National Economic Problems. Join Institute of Nuclear Research, Dubna, Russia, pp. 104-126.

13. Kalashnikov VM, Zaichick V (1977) Bone analysis of N, F and P by photonuclear activation. Voprosy Meditsinskol Khimii 23(1): 122-127.

14. Zaichick V (1993) The in vivo neutron activation analysis of calcium in the skeleton of normal subjects, with hypokinesia and bone diseases. J Radioanal Nucl Chem 169(2): 307-316.

15. Zaichick V (1994) Instrumental activation and X-ray fluorescent analysis of human bones in health and disease. J Radioanal Nucl Chem 179(2): 295-303.

16. Zaichick V, Ovchjarenko NN (1996) In vivo X-ray fluorescent analysis of $\mathrm{Ca}, \mathrm{Zn}, \mathrm{Sr}$, and $\mathrm{Pb}$ in frontal tooth enamel. J Trace Microprob Tech 14(1): 143-152.

17. Zaichick V, Morukov BV (1998) In vivo bone mineral studies on volunteers during a 370-day antiorthostatic hypokinesia test. J Appl Radiat Isot 49(5-6): 691-694.

18. Zaichick V (1998) In vivo and in vitro application of energy-dispersive XRF in clinical investigations: experience and the future. J Trace Elem Exp Med 11(4): 509-510.

19. Zaichick V, Ovchjarenko N, Zaichick S (1999) In vivo energy dispersive $\mathrm{X}$-ray fluorescence for measuring the content of essential and toxic trace elements in teeth. J Appl Radiat Isot 50(2): 283-293.

20. Zaichick V, Snetkov A (2000) Bone composition in children with rickets-like diseases before and during treatment. In: Mengen- und Spurenelemente. 20 Arbeitstagung. Friedrich-Schiller-Universität, Jena 1109-1117.

21. Zaichick V, Dyatlov A, Zaihick S (2000) INAA application in the age dynamics assessment of major, minor, and trace elements in the human rib. J Radioanal Nucl Chem 244(1): 189-193.

22. Sastri CS, Iyengar V, Blondiaux G, Tessier Y, Petri H, et al. (2001) Fluorine determination in human and animal bones by particleinduced gamma-ray emission. Fresen J Anal Chem 370(7): 924-929.

23. Zaichick V, Tzaphlidou M (2002) Determination of calcium, phosphorus, and the calcium/phosphorus ratio in cortical bone from the human femoral neck by neutron activation analysis. J Appl Radiat Isot 56(6): 781-786.

24. Tzaphlidou M, Zaichick V (2002) Neutron activation analysis of calcium/phosphorus ratio in rib bone of healthy humans. J Appl Radiat Isot 57(6): 779-783.

25. Tzaphlidou M, Zaichick V (2003) Calcium, Phosphorus, CalciumPhosphorus ratio in rib bone of healthy humans. Biol Trace Elem Res 93(1-3): 63-74.

26. Zaichick V, Tzaphlidou M (2003) Calcium and phosphorus concentrations and calcium/phosphorus ratio in trabecular bone from femoral neck of healthy humans as determined by neutron activation analysis. J Appl Radiat Isot 58(6): 623-627. 


\section{Cancer Therapy \& Oncology International Journal}

27. Zaichick V (2004) INAA application in the age dynamics assessment of $\mathrm{Ca}, \mathrm{Cl}, \mathrm{K}, \mathrm{Mg}, \mathrm{Mn}, \mathrm{Na}, \mathrm{P}$, and $\mathrm{Sr}$ contents in the cortical bone of human femoral neck. J Radioanal Nucl Chem 259(2): 351-354.

28. Zaichick V (2004) Sex and age related Ca/P ratio in trabecular bone of iliac crest of healthy humans. In: Macro and Trace Elements. 22 Workshop, Friedrich-Schiller- Universität, Jena, pp. 248-255.

29. Tzaphlidou M, Zaichick V (2004) Sex and age related Ca/P ratio in cortical bone of iliac crest of healthy humans. J Radioanal Nucl Chem 259(2): 347-349.

30. Zaichick V (2007) INAA application in the assessment of selected elements in cancellous bone of human iliac crest. J Radioanal Nucl Chem 271: 573-576.

31. Zaichick V, Zaichick S (2009) Instrumental neutron activation analysis of trace element contents in the rib bone of healthy men. J Radioanal Nucl Chem 281(1): 47-52.

32. Zaichick V (2009) Neutron activation analysis of $\mathrm{Ca}, \mathrm{Cl}, \mathrm{K}, \mathrm{Mg}, \mathrm{Mn}, \mathrm{Na}, \mathrm{P}$, and $\mathrm{Sr}$ contents in the crowns of human permanent teeth. J Radioanal Nucl Chem 281(1): 41-45.

33. Zaichick S, Zaichick V (2010) The effect of age and gender on 38 chemical element contents in human iliac crest investigated by instrumental neutron activation analysis. J Trace Elem Med Biol 24(1) $1-6$

34. Zaichick S, Zaichick V (2010) The effect of age and gender on 38 chemical element contents in human femoral neck investigated by instrumental neutron activation analysis. Biol Trace Elem Res 137(1): 1-12.

35. Zaichick S, Zaichick V (2012) Neutron activation analysis of $\mathrm{Ca}, \mathrm{Cl}$ $\mathrm{Mg}, \mathrm{Na}$, and $\mathrm{P}$ content in human bone affected by osteomyelitis or osteogenic sarcoma. J Radioanal Nucl Chem 293(1): 241-246.

36. ZaichickV (2013) Chemical elements of human bone tissue investigated by nuclear analytical and related methods. Biol Trace Elem Res 153(13): 84-99.

37. Zaichick V (2013) Data for the Reference Man: skeleton content of chemical elements. Radiat Environ Bioph 52(1): 65-85.

38. Zaichick V, Zaichick S (2014) The $\mathrm{Ca}, \mathrm{Cl}, \mathrm{Mg}, \mathrm{Na}$, and $\mathrm{P}$ mass fractions in human bone affected by Ewing's sarcoma. Biol Trace Elem Res 159(13): $32-38$

39. Zaichick V, Kalashnikov VM, Bizer VA (1980) The in vivo analysis of Ca, $\mathrm{Na}$ and $\mathrm{Cl}$ in human limb tumours by neutron activation, In: Application of Nuclear Analytical Methods in Biology and Medicine. Institute of Medical Radiology, Obninsk, Russia, p. 58-74.

40. Zaichick V, Zaichick S (1996) Instrumental effect on the contamination of biomedical samples in the course of sampling. The Journal of Analytical Chemistry 51(12): 1200-1205.

41. Zaichick V (1997) Sampling, sample storage and preparation of biomaterials for INAA in clinical medicine, occupational and environmental health. In: Harmonization of Health-Related Environmental Measurements Using Nuclear and Isotopic Techniques. INIS, Vienna, Austria, pp. 123-133.

42. Zaichick V (1995) Application of synthetic reference materials in the Medical Radiological Research Centre. Fresen J Anal Chem 352(1-2): 219-223.

43. Zaichick V, Kolotov AV, Dogadkin N (2002) Comparative analysis of major and trace elements in bone reference materials, IAEA H-5 (animal bone) and NIST SRM 1486 (bone meal). In: Macro and Trace Elements. 21 Workshops. Friedrich-Schiller- Universität, Jena, Germany, p. 39-47.

44. Korelo A, Zaichick V (1993) Software to optimize the multielement INAA of medical and environmental samples. In: Activation analysis in environment protection. Join Institute of Nuclear Research, Dubna, Russia, pp. 326-332.

45. Zaichick V (2004) Losses of chemical elements in biological samples under the dry ashing process. Trace Elements in Medicine 5(3): 17-22.

46. Zaichick S, Zaichick V (2012) Neutron activation analysis of $\mathrm{Ca}, \mathrm{Cl}$ $\mathrm{Mg}, \mathrm{Na}$, and $\mathrm{P}$ content in human bone affected by osteomyelitis or osteogenic sarcoma. J Radioanal Nucl Chem 293(1): 241-246.

47. Zaichick V, Zaichick S (2014) The $\mathrm{Ca}, \mathrm{Cl}, \mathrm{Mg}$, $\mathrm{Na}$, and $\mathrm{P}$ mass fractions in human bone affected by Ewing's sarcoma. Biol Trace Elem Res 159(13): $32-38$.

48. Leyssens L, Vinck B, Van Der Straeten C, Wuyts F, Maes L (2017) Cobalt toxicity in humans-A review of the potential sources and systemic health effects. Toxicology 387: 43-56.

49. Yu R (2017) Cobalt toxicity, An overlooked cause of hypothyroidism JETR 1(3): 1-4.

50. Simonsen LO, Harbak H, Bennekou P (2012) Cobalt metabolism and toxicology--a brief update. Sci Total Environ 432: 210-215.

51. Dermience M, Lognay G, Mathieu F, Goyens P (2015) Effects of thirty elements on bone metabolism. J Trace Elem Med Biol 32: 86-106.

52. Nigam A, Priya S, Bajpai P, Kumar S (2014) Cytogenomics of hexavalent chromium ( $\mathrm{Cr} 6+$ ) exposed cells: a comprehensive review. Indian J Med Res 139(3): 349-370.

53. Zhitkovich A (2011) Chromium in drinking water: sources, metabolism, and cancer risks. Chem Res Toxicol 24(10): 1617-1629.

54. Ding SZ, Yang YX, Li XL, Michelli-Rivera A, Han SY, et al. (2013) Epithelial-mesenchymal transition during oncogenic transformation induced by hexavalent chromium involves reactive oxygen speciesdependent mechanism in lung epithelial cells. Toxicol Appl Pharmacol 269(1): 61-71.

55. Johnson GT, Lewis TR, Wagner WD (1975) Acute toxicity of cesium and rubidium compounds. Toxicol Appl Pharmacol 32: 239-245.

56. Jones JM, Yeralan O, Hines G, Maher M, Roberts DW, et al. (1990) Effects of lithium and rubidium on immune responses of rats. Toxicol Lett 52 : 163-168.

57. Petrini M, Vaglini F, Carulli G, Azzara A, Ambrogi F, et al. (1990) Rubidium is a possible supporting element for bone marrow leukocyte differentiation. Haematologica 75(1): 27-31.

58. Xue FX, Zhang SW (1991) Selenium concentrations in serum, hair and tumor tissue from patients with ovarian tumors. Zhonghua Fu Chan $\mathrm{Ke}$ Za Zhi 26(5): 290-292.

59. Zachara BA, Marchaluk-Wiśniewska E, Maciag A, Pepliński J, Skokowsk J, et al. (1997) Decreased selenium concentration and glutathione peroxidase activity in blood and increase of these parameters in malignant tissue of lung cancer patients. Lung 175(5): 321-332.

60. Zachara BA, Szewczyk-Golec K, Tyloch J, Wolski Z, Szylberg T, et al (2005) Blood and tissue selenium concentrations and glutathione peroxidase activities in patients with prostate cancer and benign prostate hyperplasia. Neoplasma 52(3): 248-254.

61. Zaichick V,Zaichick S (2016) Trace element contents in adenocarcinoma of the human prostate gland investigated by neutron activation analysis. Cancer Research and Oncology 1(1): 1-10.

62. Zaichick V, Zaichick S (2016) Prostatic tissue levels of 43 trace elements in patients with prostate adenocarcinoma. Cancer and Clinical Oncology 5(1): 79-94.

63. Zaichick V, Zaichick S (2016) The Comparison between the contents and interrelationships of 17 chemical elements in normal and cancerous prostate gland. Journal of Prostate Cancer 1(1): 105. 


\section{Cancer Therapy \& Oncology International Journal}

64. Zaichick V, Zaichick S (2016) Distinguish between benign and malignant prostate using the trace element content ratios in prostatic tissue as tumor markers. Mathews Journal of Cancer Science 1(1): 006.

65. Zaichick V, Zaichick S (2016) Distinguishing malignant from benign prostate using content of 17 chemical elements in prostatic tissue. Integrative Cancer Science and Therapeutics 3(5): 579-587.

66. Zaichick V, Zaichick S (2017) Trace element levels in prostate gland as carcinoma's markers. Journal of Cancer Therapy 8(2): 131-145.

67. Zaichick V (2017) Differences between 66 chemical element contents in normal and cancerous prostate. Journal of Analytical Oncology 6(1): 37-56.

68. Zaichick V, Zaichick S (2017) Ratios of selenium/trace element contents in prostate gland as carcinoma's markers. Journal of Tumor Medicine and Prevention 1(2): 555556.

69. Raju GJN, Sarita P, Kumar MR, Murty G, Reddy BS, et al. (2006) Trace elemental correlation study in malignant and normal breast tissue by PIXE technique. Nucl Instrum Methods Phys Res B 247: 361-367.

70. Charalabopoulos K, Kotsalos A, Batistatou A, Charalabopoulos A Vezyraki P, et al. (2006) Selenium in serum and neoplastic tissue in breast cancer: correlation with CEA. Br J Cancer 95(6): 674-676.

71. Kucharzewski M, Braziewicz J, Majewska U, Gózdz S (2003) Selenium, copper, and zinc concentrations in intestinal cancer tissue and in colon and rectum polyps. Biol Trace Elem Res 92(1): 1-10.

72. Charalabopoulos K, Kotsalos A, Batistatou A, Charalabopoulos A, Peschos D, et al. (2009) Serum and tissue selenium levels in gastric cancer patients and correlation with CEA. Anticancer Res 29(8): 34653467.

73. Zaichick V, Zaichick S (2018) Trace Element Contents in Thyroid Cancer Investigated by Instrumental Neutron Activation Analysis. Journal of Oncology Research 2(1): 1-13.

74. Zaichick V, Zaichick S (2015) The content of silver, cobalt, chromium, iron, mercury, rubidium, antimony, selenium, and zinc in osteogenic sarcoma. Journal of Cancer Therapy 6(6): 493-503.

75. Zaichick V, Zaichick S (2015) The silver, cobalt, chromium, iron, mercury, rubidium, antimony, selenium, and zinc contents in human bone affected by chondrosarcoma. Journal of Hematology and Oncology Research 1(4): 25-36.

76. Zaichick V, Zaichick S (2015) The content of silver, cobalt, chromium, iron, mercury, rubidium, antimony, selenium, and zinc in malignant giant cell tumor of bone. Archive in Cancer Research 3(4): 1-9.

77. Gupta-Elera G, Garrett AR, Robison RA, O’Neill KL (2012) The role of oxidative stress in prostate cancer. Eur J Cancer Prev 21(2): 155-162.

78. Al-Ebraheem A, Farquharson MJ, Ryan E (2009) The evaluation of biologically important trace metals in liver, kidney and breast tissue. J Appl Radiat Isot 67: 470-474

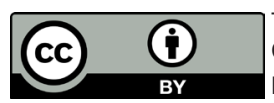

This work is licensed under Creative

Commons Attribution 4.0 License

DOI: 10.19080/CTOIJ.2018.09.555767
79. Tashiro H, Kawamoto T, Okubo T, Koide $O$ (2003) Variation in the Distribution of Trace Elements in Hepatoma. Biol Trace Elem Res 95(1): 49-63.

80. Gumulec J, Masarik M, Adam V, Eckschlager T, Provaznik I, Kizek R (2014) Serum and tissue zinc in epithelial malignancies: a metaanalysis. PLoS One 9(6): e99790.

81. Zhong H, Tan M, Fu Y, Huang J, Tang Z (2014) Determination of trace elements in tissue of human uterine cancer by instrumental neutron activation analysis. Biol Trace Elem Res 71-72: 569-574.

82. Díez M, Arroyo M, Cerdàn FJ, Muñoz M, Martin MA, et al. (1989) Serum and tissue trace metal levels in lung cancer. Oncology 46(4): 230-234.

83. Zaichick V, Sviridova T, Zaichick S (1997) Zinc in human prostate gland: normal, hyperplastic and cancerous. Int Urol Nephrol 29(5): 565-574.

84. Zaichick S, Zaichick (2010) Method and portable facility for energydispersive X-ray fluorescent analysis of zinc content in needle-biopsy specimens of prostate. X-Ray Spectrom 39(2): 83-89.

85. ZaichickV,Zaichick S (2016) Trace element contents in adenocarcinoma of human prostate investigated by energy dispersive X-ray fluorescent analysis. Journal of Adenocarcinoma 1(1): 1-7.

86. Yaman M (2006) Comprehensive comparison of trace metal concentrations in cancerous and non-cancerous human tissues. Curr Med Chem 13(21): 2513-2525.

87. Mulware SJ (2013) Comparative Trace Elemental Analysis in Cancerous and Noncancerous Human Tissues Using PIXE. Journal of Biophysics 2013: 192026.

88. Sun Z-G, Song G-M, Zhang M, Wang Z (2011) Clinical study on zinc, copper and manganese levels in patients with esophageal squamous cell cancer. J Trace Elem Electrolytes 28: 116-120.

89. Zaichick V, Zaichick S, Wynchank S (2016) Intracellular zinc excess as one of the main factors in the etiology of prostate cancer. Journal of Analytical Oncology 5(3): 124-131.

90. Sunderman FW (1979) Mechanism of metal carcinogenesis. Biol Trace Elem Res 1: 63-86.

91. Snow ET (1992) Metal carcinogenesis: mechanistic implications Pharmacol Ther 53(1): 31-65.

92. Koedrith P, Kim H, Weon JI, Seo YR (2013) Toxicogenomic approaches for understanding molecular mechanisms of heavy metal mutagenicity and carcinogenicity. Int J Hyg Environ Health 216(5): 587-598.

93. Salnikow K, Zhitkovich A (2008) Genetic and epigenetic mechanisms in metal carcinogenesis and cocarcinogenesis: nickel, arsenic, and chromium. Chem Res Toxicol 21(1): 28-44.

\begin{tabular}{l} 
Your next submission with Juniper Publishers \\
will reach you the below assets \\
- Quality Editorial service \\
- Swift Peer Review \\
- Reprints availability \\
- E-prints Service \\
- Manuscript Podcast for convenient understanding \\
- Global attainment for your research \\
- Manuscript accessibility in different formats \\
( Pdf, E-pub, Full Text, Audio) \\
- Unceasing customer service \\
Track the below URL for one-step submission \\
https://juniperpublishers.com/online-submission.php \\
\hline
\end{tabular}

